\title{
Validation of Diaporthe toxica resistance markers in European Lupinus angustifolius germplasm and identification of novel resistance donors for marker-assisted selection
}

\author{
M. Książkiewicz ${ }^{1}$ - K. Wójcik ${ }^{1}$ - W. Irzykowski ${ }^{1}$ - W. Bielski ${ }^{1}$ - S. Rychel ${ }^{1} \cdot$ J. Kaczmarek $^{1}$ • P. Plewiński ${ }^{1} \cdot$ E. Rudy $^{1}$. \\ M. Jędryczka ${ }^{1}$ (D)
}

Received: 29 April 2019 / Revised: 22 August 2019 / Accepted: 3 September 2019 / Published online: 22 October 2019

(C) The Author(s) 2019

\begin{abstract}
The fungus, Diaporthe toxica, anamorph Phomopsis sp., previously classified as P. leptostromiformis, is a plant endophyte and occasional pathogen, causing Phomopsis stem blight. This disease is damaging not only to lupins but also to the animals grazing on infected plants, due to the toxic secondary metabolites called phomopsins. The aim of this work was to validate markers for resistance to Phomopsis stem blight in narrow-leafed lupins and identify novel germplasm with increased levels of resistance to the disease. Plant inoculations were performed using ten isolates of D. toxica, originating from Australia and Poland. The European core collection of L. angustifolius was evaluated both in a controlled environment and with field experiments to classify the accessions based on their resistance to the disease. Simultaneously, the accessions were assayed with disease resistance markers to identify donors of hypothetical resistance alleles. We have found that the European lupin germplasm collection preserves wild and domesticated donors of at least two resistance genes to Phomopsis stem blight, including Phrl and $P h t j R$. Molecular markers PhtjM7, InDel2, and InDel10, tagging PhtjR gene, were applicable for marker-assisted selection targeting the European gene pool with an expected accuracy of $95 \%$. None of diagnostic markers for the Phrl locus was found useful for European breeding programs; two existing markers Ph258M1 and Ph258M2 were unreliable, due to a high percentage of false-positive results (up to 58\%) and a high recombination rate between markers $(\sim 30 \%)$.
\end{abstract}

Keywords Narrow-leafed lupin $\cdot$ Molecular breeding $\cdot$ Pathogenic fungus $\cdot$ Phomopsis stem blight $\cdot$ Phrl $\cdot$ PhtjR

\section{Introduction}

The legume Lupinus angustifolius L. (narrow-leafed lupin) belongs to the genus Lupinus (tribe of Genisteae, family Fabaceae, subfamily Faboideae). It is well known as a source of protein for food and feed, as well as being a crop that contributes to the improvement of soil structure and fertility, increasing yields of succeeding crops (Peoples et al. 2009).

Communicated by: Barbara Naganowska

Electronic supplementary material The online version of this article (https://doi.org/10.1007/s13353-019-00521-y) contains supplementary material, which is available to authorized users.

M. Jędryczka

mjed@igr.poznan.pl

1 Institute of Plant Genetics, Polish Academy of Sciences, Strzeszynska 34, 60-479 Poznań, Poland
Registered lupin cultivars are characterized by moderate grain yield with a high content of protein and oil, accompanied by low alkaloid content and limited fiber (Cernay et al. 2015; Lucas et al. 2015). Due to its relatively low chromosome number $(2 \mathrm{n}=40)$ and small genome size $(2 \mathrm{C}=1.89 \mathrm{pg})$, compared with other lupins (Naganowska et al. 2003), L. angustifolius became the species of choice for extensive molecular studies. Molecular research has been greatly facilitated by the development of bacterial artificial chromosome (BAC) libraries of the nuclear genomes for two L. angustifolius cultivars: Polish cv. Sonet (Kasprzak et al. 2006) and Australian cv. Tanjil (Gao et al. 2011). Highdensity linkage maps carrying thousands of markers, including gene-based sequence tagged sites (STS), were constructed and aligned to the draft genome sequence (Hane et al. 2017; Kamphuis et al. 2015; Nelson et al. 2006; Yang et al. 2013b). Exploitation of BAC resources for cytogenetic mapping resulted in the integration of all linkage groups with the corresponding chromosomes, as well as in the identification of 
several gene-rich regions (Książkiewicz et al. 2013, 2015; Leśniewska et al. 2011; Przysiecka et al. 2015; Wyrwa et al. 2016). The release of reference transcriptomes for wild and domesticated lupin accessions constituted a platform for targeting particular genes of interest (Kamphuis et al. 2015).

Despite its dynamic domestication history and high nutritional value, worldwide use of lupin for livestock feed has been hampered by high alkaloid content and the risk of lupinosis disease. The alkaloid issue has been almost entirely solved due to the discovery of three heritable factors decreasing alkaloid content (iucundus, depressus, and esculentus) (Hackbarth and Troll 1956). Incorporation of these alleles into breeding lines resulted in development of germplasm with a greatly reduced total alkaloid level, more than hundredfold lower than that of old cultivars (Kamel et al. 2016). However, lupinosis still remains a serious threat for animals grazing on lupin stubble (Cowley et al. 2014). The chemical factor causing lupinosis was revealed to be a phomopsin, a toxin produced by pathogenic fungi, Diaporthe toxica Will., Highet, Gams \& Sivasith, anamorph Phomopsis sp. (Jago et al. 1982; Williamson et al. 1994). As the toxin is produced during the latent stage of stem infection of susceptible plants, exploitation of heritable resistance resources is a prerequisite of further lupin improvement. The fungus, formerly known as Phomopsis leptostromiformis (Kühn) Bubák, causes the lupin disease Phomopsis stem blight. Methods of screening for Phomopsis stem blight rely on observations of lesion coverage as percentage surface area on senescent stems (Cowling et al. 1987) or staining and microscopic examination of subcuticular coralloid hyphae structures of infected stems (Williamson et al. 1991). Additionally, a non-destructive glasshouse infection test has been developed, based on inoculation of lateral branches regenerating from the second main stem node, after topping the main stem above this node (Shankar et al. 2002). Over many years, D. toxica has been a major problem in Australia, where lupin was introduced as a winter crop. Australian breeders responded with the introduction of a moderately resistant wild population line from Morocco, CPI65211A, into a cross derivative of cv. Marri and P22872, which resulted in development of elite breeding line, 75A:258 (Cowling et al. 1987). The line is still used as a reference in phytopathological assays as its Phomopsis stem blight resistance has never been broken despite wide implementation of this genotype in Australian breeding programs (Shankar et al. 1996, 2002; Stefanova and Buirchell 2010; Yang et al. 2015, 2013a, 2002). In Europe, D. toxica seems to be a dormant pathogen as reports of the disease date from as early as 1880 in Germany and in 1892 in Denmark (on L. angustifolius and L. luteus) but it has never caused serious problems (Fischer 1893; Lind 1913). Although it has appeared from time to time in different countries in Europe, including Poland and Russia (Lewartowska et al. 1994; Marcinkowska 2007).
Australian lupin collection revealed extensive accession-related diversity in the severity of disease symptoms developed, from very susceptible lines (Unicrop, Uniharvest, Uniwhite), through susceptible (Chittick, Danja, Geebung), somewhat resistant (Merrit, Tanjil, and Wonga), to highly resistant (75A:258) (Yang et al. 2015; 2002). There are at least three different genetic sources of $D$. toxica resistance in L. angustifolius, all originating from an Australian collection. Reference germplasm resources for these genes are line 75A:258 (Phrl gene), cultivar Merrit (Phr2) and cv. Tanjil $(P h t j R)$. With the use of the molecular fragment length polymorphism (MFLP) technique, markers linked to the putative Phrl resistance gene were designed, Ph258M1 and Ph258M2 (Yang et al. 2002). Next-generation sequencing of restriction site-associated DNA fragments was exploited to develop a set of single nucleotide polymorphism (SNP) markers linked to the PhtjR gene, namely PhtjM4, PhtjM5, and PhtjM7 (Yang et al. 2013a). Recently, a whole-genome resequencing approach was harnessed to develop a new set of low-cost markers tagging the $P h t j R$ gene, including insertion/deletion PCR markers Markers InDel2 and InDel10, were found to be an effective diagnostic method on a broad range of Australian commercial cultivars (Yang et al. 2015).

Numerous undesired traits were eliminated during the history of narrow-leafed lupin domestication, including vernalization responsiveness, pod shattering, hard seed coat, bitter taste, and susceptibility to anthracnose. L. angustifolius breeding programs are most advanced in Australia; however, this process was largely based on two European genotypes (Borre and New Zealand Blue) and subsequently only occasionally improved with externally sourced germplasm (Berger et al. 2012). Only a small fraction of the available genetic and adaptive diversity was exploited during the domestication process of the species (Berger et al. 2013). Australian D. toxica-resistant cultivars cannot be exploited as highly transferable donors of resistance alleles due to significant genetic diversity constraints. The necessity for exploitation of wild populations and primitive forms to bypass the domestication bottleneck has emerged.

To address limitations of current breeding programs, we decided to leverage sources of $D$. toxica resistance from European L. angustifolius germplasm combining markerassisted and classical approaches. Here, diagnostic procedures of Phomopsis stem blight resistance markers were optimized and the European core collection of $L$. angustifolius was assayed with these markers to identify hypothetical donors of resistance alleles. The resistance of selected narrow-leafed lupin lines was evaluated both in controlled environment tests and in field experiments to validate marker-trait associations as well as to identify novel germplasm with increased levels of Phomopsis stem blight resistance. 


\section{Materials and methods}

\section{Isolates of Diaporthe toxica}

A collection of ten isolates of $D$. toxica was established (Table 1). Five isolates were collected from $L$. luteus plants, with four cultivated on fields located in the Wiatrowo Breeding Station of Poznan Plant Breeders and one was growing in the wild in Western Australia. The other five isolates were obtained from $L$. angustifolius, all of them were collected in Australia, mostly in Western Australia (4 sites) and one isolate was obtained from $L$. angustifolius collected in South Eastern Australia. The cultures of D. toxica (Phomopsis) were grown on PDA medium and the sporulation was induced under NUV light in growth chambers at $20{ }^{\circ} \mathrm{C}$ in the darkness.

\section{Preliminary resistance survey}

This experiment was conducted in 2007 in a phytotron (MYTRON Bio-und Solartechnik GmbH, Heiligenstadt) in controlled conditions (temperature regime $20^{\circ} \mathrm{C}$ day/ $15{ }^{\circ} \mathrm{C}$ night, with 14 -h day/10-h night photoperiod). Plants were grown in pots filled with sterilized soil substrate (Klassmann TS3 601 supplemented with the fertilizer PG Mix (Hartmann Ltd., PL). For each plant/pathogen combination, there were 10 plants treated in 3 replicates and 10 plants for mock inoculation. Lower parts of stems of 28day plants were scarified by lancet ( $2 \mathrm{~cm}$ from root neck) and inoculated with $20 \mu \mathrm{L}$ of conidia suspension of a given isolate of $D$. toxica $\left(10^{6}\right.$ conidia per $\left.\mathrm{ml}\right)$. After inoculation, plants were grown in at least $80 \%$ relative humidity and a temperature regime of $22{ }^{\circ} \mathrm{C}$ day/19-20 ${ }^{\circ} \mathrm{C}$ night. High humidity (above $80 \%$ ) was maintained using HADAR micro-sprinklers (NaanDanJain Irrigation, Naan, Israel). The test was performed using L. luteus Juno (Polish susceptible cultivar) and four L. angustifolius accessions: Sonet (Polish cultivar formerly used for BAC library development), breeding line 258 (Australian breeding line 75A:258 carrying putative resistance gene Phrl), Unicrop (Australian susceptible cultivar), and Tanjil (Australian cultivar carrying the putative resistance gene $P h t j R$ ). Four isolates were used for inoculation, Polish DTOX1 and DTOX4, and Australian DTOXA1 and DTOXA2 isolates (Table 1). The number of plants with visible Phomopsis stem blight symptoms was counted and expressed as percent of infected plants. Disease severity was scored $3,7,14,21$, and 30 days after inoculation and evaluated using the following scale:

0 -resistance, no visible disease symptoms.

1 -limited susceptibility, small light brown spots on the lower part of the main stem.

2-moderate susceptibility, medium-size brown lesions with isolated pycnidia.

3-high susceptibility, large brown lesions dispersed over all parts of the stem with pycnidia.

4 - very high susceptibility, the whole stem covered by brown lesions with numerous pycnidia.

Statistical analysis of variance (ANOVA) was performed.

\section{Disease resistance evaluation in controlled conditions}

Three experiments in a controlled environment (greenhouse) were performed in 2007 and 2008 (temperature regime $20{ }^{\circ} \mathrm{C}$ day $/ 15^{\circ} \mathrm{C}$ night). Seeds were sown in pots filled with sterilized soil. A total of 10 plants $\times 3$ repeats for each line/ pathogen combination and 10 plants for mock inoculation were assayed. The set of 26 L. angustifolius accessions analyzed in this survey contained 18 cultivars, 7 breeding lines, and one wild population (Online Resource 1). Inoculation was done using DTOX3 isolate. After inoculation, plants were grown with a relative humidity above $80 \%$ and a temperature regime of $22{ }^{\circ} \mathrm{C}$ day $/ 19-20{ }^{\circ} \mathrm{C}$ night. The scoring of disease severity was performed 30 days after inoculation, using the same method as in the preliminary $D$. toxica resistance survey.
Table 1 The isolates of Diaporthe toxica used in this study

\begin{tabular}{lllllll}
\hline No. & Isolate symbol & Host plant & Cultivar & Region & Location & Year \\
\hline 1 & DTOX1 & L. luteus & Juno & Greater Poland & Wiatrowo & 2007 \\
2 & DTOX2 & & Mister & & & \\
3 & DTOX3 & & Parys & & & \\
4 & DTOX4 & & Juno & & Green Bushes & No data \\
5 & WAC 8787 & L. angustifolius & wild plant & Western Australia & Perth & \\
6 & DTOXA1 & & & & Perth & \\
7 & DTOXA2 & & & & Kojonup & \\
8 & WAC9513 & & & & Wongan Hills & \\
9 & WAC8771 & & & South Eastern Australia & Wagga Wagga & \\
10 & WAC8782 & & & & &
\end{tabular}




\section{Disease resistance assessment in field experiments}

Field assays of Phomopsis stem blight resistance were performed in 2008-2009 from May to August at an area of $10 \times 25 \mathrm{~m}$, with $2 \times 1 \mathrm{~m}$ of each plot. The cultivars of L. angustifolius (18) and L. luteus (7) delivered by Poznan Plant Breeders (breeding station Wiatrowo) and Plant Breeding Smolice Ltd., Co. (breeding station Przebędowo) were used (Online Resource 1). The experimental design comprised 3 replicates of inoculated plants and 1 control. Each replicate consisted of 3 field sections totaling 75 plants. Inoculation procedure, humidity control, and disease severity assessments were performed using the same methods as those used in the preliminary D. toxica resistance survey.

\section{PCR conditions}

Primers were designed using Primer3Plus (Untergasser et al. 2007). Each PCR reaction was performed in a total volume of $20 \mu \mathrm{l}$ in 96-well twin.tec PCR plates (Eppendorf, Hamburg, Germany) using 0.5 U Taq DNA Polymerase Recombinant (Invitrogen Thermo Fisher Scientific, Waltham, USA), 1× PCR buffer, $2 \mathrm{mM} \mathrm{Mg}^{2+}, 0.25 \mathrm{mM}$ dNTP, $0.25 \mu \mathrm{M}$ of each primer, and 50 ng DNA template and deionized water. The amplification protocol included an initial denaturation at $94{ }^{\circ} \mathrm{C}$ for $4 \mathrm{~min}$, followed by 35 cycles of annealing (45$62{ }^{\circ} \mathrm{C}$ for $\left.30 \mathrm{~s}\right)$, elongation $\left(72{ }^{\circ} \mathrm{C}\right.$ for $40 \mathrm{~s}$ ) and denaturation $\left(94^{\circ} \mathrm{C}\right.$ for $\left.30 \mathrm{~s}\right)$, and a final elongation step $\left(72^{\circ} \mathrm{C}\right.$ for $\left.6 \mathrm{~min}\right)$.

\section{Molecular marker detection-optimization and scoring}

DNA was isolated from 3-week-old leaves using the DNeasy Plant Mini Kit (Qiagen, Hilden, Germany) according to the protocol. Two biological replicates were performed. The quality and concentration of isolated DNA were evaluated by two methods: agarose gel electrophoresis followed by ethidium bromide staining and spectrophotometer measurements (NanoDrop 2000; ThermoScientific, Waltham, USA). PCR primers (Table 2) were designed for the following markers tagging resistance genes: Ph258M1 and Ph258M2 for Phr1 gene, and PhtjM7, InDel2 and InDel10 for PhtjR (Yang et al. 2015, 2013a, 2002).

The optimization procedure involved PCR amplification using DNA isolated from reference $L$. angustifolius lines as a template (Tanjil, 75A:258, Unicrop) and amplicon sequencing. A range of annealing temperatures from 52 to $68^{\circ} \mathrm{C}$ was tested. Length polymorphisms were visualized by $1 \%$ agarose gel electrophoresis (markers Ph258M1, InDel2, and InDel10), whereas nucleotide substitution polymorphisms were detected by the cleaved amplified polymorphic sequence (CAPS) (Konieczny and Ausubel 1993) and derived CAPS (dCAPS) (Neff et al. 1998) approaches (markers Ph258M2, PhtjM4,
PhtjM5, and PhtjM7). Restriction sites were identified using dCAPS Finder 2.0 (Neff et al. 2002). Restriction products were separated by $1-3 \%$ agarose gel electrophoresis, with the agarose concentration adjusted according to the size of the expected digestion products.

The screening procedure was performed using Ph258M1, Ph258M2 dCAPS, PhtjM7 dCAPS2, InDel2, and InDel10 markers. The $L$. angustifolius germplasm collection used for genotyping consisted of 218 lines originating from 17 countries and differing by domestication status - which ranged from wild or primitive lines (76) through mutants (5) and cross derivatives/breeding lines (65) to cultivars (74) (Online Resource 1).

\section{Validation of markers by disease resistance assay}

The validation assay was done using 49 lines. The experiment was done in controlled environment in 2017 based on the results of $L$. angustifolius phenotyping against Phomopsis stem blight resistance and genotyping with $\mathrm{Ph} 258 \mathrm{M} 1$, $\mathrm{Ph} 258 \mathrm{M} 2$, PhtjM7, InDel2, and InDel10 markers. The inoculation of plants was done using two isolates showing the highest virulence against $L$. angustifolius (DTOXA2 and WAC8782). Inoculation method was similar to that used in greenhouse tests performed in 2007-2008. Disease scoring was done using the scale from 1 (immune, no symptoms) to 9 (fully susceptible with all symptoms typical to Phomopsis stem blight). Markers were validated by comparing the marker genotype with resistance phenotype by binary data similarity analysis. Taking into consideration the hypothesis that $D$. toxica resistance is conferred by dominant alleles (Shankar et al. 2002; Yang et al. 2002, 2013a), heterozygote and resistant homozygote marker scores were assigned as 1 and susceptible homozygote scores as 0 . The same was done for phenotype observations - resistant and moderately resistant lines were marked as 1 and susceptible were marked as 0 . Simple matching (Sokal and Michener 1958) and RogersTanimoto (Rogers and Tanimoto 1960) coefficients were calculated using Binary Similarity Calculator http://www. minerazzi.com/tools/similarity/binary-similarity-calculator. php. Rogers-Tanimoto is a modification of the simple matching parameter that assigns double weight to mismatching variables, therefore emphasizing false-positive and false-negative scores.

\section{Results}

\section{Germplasm resources resistant to $D$. toxica are preserved in the European L. angustifolius gene bank}

The disease resistance survey under controlled conditions revealed that most of the analyzed $L$. angustifolius germplasm 
Table 2 Primers used for optimization of Diaporthe toxica resistance markers

\begin{tabular}{|c|c|c|c|c|c|}
\hline Marker & Primer sequences ${ }^{\mathrm{a}}$ & $\begin{array}{l}\text { Target } \\
\text { resistance } \\
\text { gene }\end{array}$ & $\begin{array}{l}\text { Enzyme and } \\
\text { recognized } \\
\text { sequence }\end{array}$ & $\begin{array}{l}\text { Product lengths } \\
\text { for resistant } \\
\text { line (bp) }\end{array}$ & $\begin{array}{l}\text { Product lengths } \\
\text { for susceptible } \\
\text { line (bp) }\end{array}$ \\
\hline Ph258M1 & $\begin{array}{l}\text { TCCAGACTGACTATATTCTTAG } \\
\text { CAGGCACATATATCTTTATACC }\end{array}$ & Phrl & - & 303 & 254 \\
\hline $\begin{array}{l}\mathrm{Ph} 258 \mathrm{M} 2- \\
\text { dCAPS }\end{array}$ & $\begin{array}{l}\text { GGGAACAACAACAACAACTA } \\
\text { GAACCATTGTAACTAAATCC }\end{array}$ & Phrl & $\begin{array}{l}\text { MaeI } \\
\text { CTAG }\end{array}$ & 18,185 & 206 \\
\hline PhtjM4_dCAPS1 & $\begin{array}{l}\text { TTCAACCAACGTGGGACTTAAATAGT } \\
\text { TAA } \\
\text { GTGGATACAACCTCACTGTC }\end{array}$ & $P h t j R$ & $\begin{array}{l}\text { HindII } \\
\text { GTYRAC }\end{array}$ & 89 & 25,64 \\
\hline PhtjM4_dCAPS2 & $\begin{array}{l}\text { CAACCAACGTGGGACTTAAATATTTAA } \\
\text { GTGGATACAACCTCACTGTC }\end{array}$ & PhtjR & $\begin{array}{l}\text { AhaIII } \\
\text { TTTAAA }\end{array}$ & 23,64 & 87 \\
\hline PhtjM5_CAPS & $\begin{array}{l}\text { GAATTCCATATGCAATGG } \\
\text { CTTAATTGTTAATTTGTTATTTGC }\end{array}$ & PhtjR & $\begin{array}{l}\text { CviJI } \\
\text { RGCY }\end{array}$ & 90 & 17,73 \\
\hline PhtjM7_dCAPS1 & $\begin{array}{l}\text { CTTCAATTAGCTTGTCAGAAGACTTCCA } \\
\text { CTAATTCAATGAGCTTCTCTT }\end{array}$ & PhtjR & $\begin{array}{l}\text { NlaIII } \\
\text { CATG }\end{array}$ & 27,49 & 76 \\
\hline PhtjM7_dCAPS2 & $\begin{array}{l}\text { TTCAATTAGCTTGTCAGAAGACTCCAA } \\
\text { CTAATTCAATGAGCTTCTCTT }\end{array}$ & PhtjR & $\begin{array}{l}\text { StyI } \\
\text { CCWWGG }\end{array}$ & 75 & 24,51 \\
\hline InDel2 & $\begin{array}{l}\text { GATAAAGTATATCTAAATTATGTTTGC } \\
\text { CTATATTTTGTATCAATTATAACAAATT }\end{array}$ & $P h t j R$ & - & 134 & 122 \\
\hline InDel10 & $\begin{array}{l}\text { GTTAAGTGGTAAATTGACTCATG } \\
\text { GTTTTRCATTCTTGCAAAGATAAAATTAG }\end{array}$ & PhtjR & - & 103 & 96 \\
\hline
\end{tabular}

${ }^{\mathrm{a}}$ The list contains primers developed in this study as well as those previously published (Yang et al. 2015, 2013a, 2002)

accessions were susceptible to $D$. toxica during the latent phase of the infection (Table 3, Online Resource 2). Susceptibility was demonstrated by the extensive colonization of stem tissues and formation of pycnidia. Susceptible lines were characterized both by high average disease severity scores and a high percentage of plants with visible disease symptoms. However, Australian cultivar Tanjil and German cultivar Arabella as well as Polish (W-226 and WTD-1406) and Australian (83A:476) breeding lines showed high levels of resistance to the pathogen, manifested by the lack of developed disease symptoms. Australian cultivar Myaille as well as Polish cultivar Bojar and German cultivar Boruta exhibited moderate resistance, with considerably delayed colonization of stem tissues and the development of only small light brown spots, limited to the lower part of the main stems.

The field disease resistance survey included several L. angustifolius cultivars previously characterized in the controlled environment experiment as susceptible (Sonet, Karo, Zeus, Mirela, Graf, Elf, Kalif, Baron), moderately resistant (Bojar, Boruta), or resistant (Arabella), as well as seven L. luteus cultivars not yet evaluated for D. toxica susceptibility. Breeding lines were not assayed due to seed availability constraints. The results obtained for $L$. angustifolius-resistant and moderately resistant lines were consistent with those from the controlled environment experiment; however, some differences in the percentage of colonized plants or disease severity symptoms were observed, for example Bojar turned out to be less susceptible than Boruta. Moreover, significant differences in developed disease symptoms between field and controlled environment assessments were observed for L. angustifolius susceptible lines Kalif, Elf, and Graf, which had very low (Graf) or low (Elf and Kalif) levels of stem tissue colonization by $D$. toxica. All analyzed $L$. luteus cultivars exhibited high susceptibility to D. toxica (Table 3, Online Resource 2).

\section{Markers tagging $D$. toxica resistance genes are relevant to PCR-based genotyping}

PCR products of markers Ph258M1, Ph258M2, PhtjM4, PhtjM5, PhtjM7, InDel2, and InDel10 (Yang et al. 2015, 2013a, 2002) were amplified using DNA isolated from reference lines (resistant and susceptible), sequenced, and compared with the target sequences. Amplification products with appropriate sequences were obtained for all analyzed markers. Markers Ph258M1, InDel2, and InDel10 were not sequenced as they were based on length differences of the amplified PCR products which could be directly visualized by simple agarose gel electrophoresis. Optimization was performed for certain markers: Ph258M2 - anchored in a simple sequence repeat (SSR) locus; as well as PhtjM4, PhtjM5, and PhtjM7-tagging single nucleotide polymorphisms (SNPs). Ph258M2, PhtjM4, and PhtjM7 markers were converted to dCAPS markers, whereas PhtjM5 was converted to a CAPS marker (Table 2). Genotyping attempts with the use of reference lines and selected wild and domesticated accessions revealed that markers PhtjM4 dCAPS 1, PhtjM4_dCAPS2, PhtjM5_CAPS, and PhtjM7_dCAPS1 had a very low rate of reproducibility resulting from weak 
Table 3 Results of Diaporthe toxica resistance assay in controlled environment (CE) and in field conditions

\begin{tabular}{|c|c|c|c|c|c|c|c|c|}
\hline Species & Acc. & Line name & $\begin{array}{l}\mathrm{CE} \\
\text { resistance }\end{array}$ & $\begin{array}{l}\text { CE average } \\
\text { score }\end{array}$ & $\begin{array}{l}\text { CE average } \\
\text { percentage }\end{array}$ & $\begin{array}{l}\text { Field } \\
\text { resistance }\end{array}$ & $\begin{array}{l}\text { Field average } \\
\text { score }\end{array}$ & $\begin{array}{l}\text { Field average } \\
\text { percentage }\end{array}$ \\
\hline \multirow[t]{7}{*}{ L. luteus } & 98072 & Juno & - & - & - & $\mathrm{S}$ & $4.0 \pm 0.0$ & $88.5 \pm 4.9$ \\
\hline & 98153 & Lord & - & - & - & $\mathrm{S}$ & $4.0 \pm 0.0$ & $74.0 \pm 9.9$ \\
\hline & 98145 & Mister & - & - & - & $\mathrm{S}$ & $3.0 \pm 0.0$ & $53.5 \pm 13.4$ \\
\hline & 98136 & Parys & - & - & - & $\mathrm{S}$ & $4.0 \pm 0.0$ & $67.5 \pm 7.8$ \\
\hline & 98154 & Perkoz & - & - & - & $\mathrm{S}$ & $3.5 \pm 0.7$ & $65.0 \pm 14.1$ \\
\hline & 98150 & Talar & - & - & - & $\mathrm{S}$ & $3.5 \pm 0.7$ & $74.5 \pm 31.8$ \\
\hline & 98148 & Taper & - & - & - & $\mathrm{S}$ & $3.5 \pm 0.7$ & $81.5 \pm 0.7$ \\
\hline \multirow[t]{26}{*}{ L. angustifolius } & - & Arabella & $\mathrm{R}$ & $0.0 \pm 0.0$ & $0 \pm 0$ & $\mathrm{R}$ & $0.5 \pm 0.7$ & $12.5 \pm 9.2$ \\
\hline & 96210 & Baron & $\mathrm{S}$ & $3.0 \pm 0.0$ & $78 \pm 10$ & MR & $1.0 \pm 0.0$ & $45.5 \pm 24.7$ \\
\hline & 96225 & Bojar & MR & $0.3 \pm 0.6$ & $28 \pm 48$ & $\mathrm{R}$ & $0.0 \pm 0.0$ & $2.0 \pm 2.8$ \\
\hline & 96211 & Boruta & MR & $0.7 \pm 0.6$ & $16 \pm 15$ & MR & $1.0 \pm 0.0$ & $16.5 \pm 4.9$ \\
\hline & 96209 & Elf & $\mathrm{S}$ & $3.0 \pm 0.0$ & $78 \pm 9$ & $\mathrm{~S}$ & $2.0 \pm 0.0$ & $18.5 \pm 6.4$ \\
\hline & 96218 & Graf & $\mathrm{S}$ & $3.0 \pm 0.0$ & $88 \pm 4$ & $\mathrm{R}$ & $0.0 \pm 0.0$ & $0.0 \pm 0.0$ \\
\hline & 96219 & Kalif & $\mathrm{S}$ & $2.0 \pm 1.0$ & $85 \pm 4$ & MR & $1.0 \pm 0.0$ & $24.5 \pm 14.8$ \\
\hline & 95964 & Karo & $\mathrm{S}$ & $3.0 \pm 0.0$ & $83 \pm 7$ & $\mathrm{~S}$ & $3.0 \pm 0.0$ & $73.5 \pm 9.2$ \\
\hline & 95796 & Mirela & $\mathrm{S}$ & $2.3 \pm 0.6$ & $81 \pm 12$ & $\mathrm{~S}$ & $3.0 \pm 0.0$ & $68.0 \pm 4.2$ \\
\hline & 96185 & Sonet & $\mathrm{S}$ & $3.0 \pm 0.0$ & $81 \pm 18$ & $\mathrm{~S}$ & $3.0 \pm 0.0$ & $91.5 \pm 3.5$ \\
\hline & 96212 & Zeus & $\mathrm{S}$ & $3.0 \pm 0.0$ & $84 \pm 10$ & $\mathrm{~S}$ & $3.0 \pm 0.0$ & $51.5 \pm 2.1$ \\
\hline & 96233 & $83 \mathrm{~A}: 476$ & $\mathrm{R}$ & $0.0 \pm 0.0$ & $0 \pm 0$ & - & - & - \\
\hline & 96121 & Emir & $\mathrm{S}$ & $2.7 \pm 0.6$ & $90 \pm 12$ & - & - & - \\
\hline & 96230 & Mandelup & S & $2.3 \pm 0.6$ & $88 \pm 11$ & - & - & - \\
\hline & 96231 & Myallie & MR & $1.0 \pm 1.7$ & $22 \pm 39$ & - & - & - \\
\hline & 96234 & P27255 & $\mathrm{S}$ & $2.3 \pm 0.6$ & $76 \pm 14$ & - & - & - \\
\hline & 96163 & Polonez & $\mathrm{S}$ & $3.0 \pm 0.0$ & $80 \pm 8$ & - & - & - \\
\hline & 96214 & Tanjil & $\mathrm{R}$ & $0.0 \pm 0.0$ & $0 \pm 0$ & - & - & - \\
\hline & 96102 & Unicrop & $\mathrm{S}$ & $4.0 \pm 0.0$ & $98 \pm 4$ & - & - & - \\
\hline & 96222 & W-197 & $\mathrm{S}$ & $2.7 \pm 0.6$ & $77 \pm 3$ & - & - & - \\
\hline & 96223 & $\mathrm{~W}-211$ & $\mathrm{~S}$ & $3.0 \pm 0.0$ & $88 \pm 7$ & - & - & - \\
\hline & 96224 & W-226 & $\mathrm{R}$ & $0.0 \pm 0.0$ & $0 \pm 0$ & - & - & - \\
\hline & 96196 & W-89 & $\mathrm{S}$ & $2.3 \pm 0.6$ & $88 \pm 0$ & - & - & - \\
\hline & 96183 & Wersal & $\mathrm{S}$ & $2.7 \pm 0.6$ & $78 \pm 8$ & - & - & - \\
\hline & 96220 & WTD-1305 & $\mathrm{S}$ & $3.0 \pm 0.0$ & $78 \pm 5$ & - & - & - \\
\hline & 96221 & WTD-1406 & $\mathrm{R}$ & $0.0 \pm 0.0$ & $0 \pm 0$ & - & - & - \\
\hline
\end{tabular}

$a c c$. accession, $C E$ controlled environment. Resistance evaluation codes: $R$ resistant, $M R$ moderately resistant, $S$ susceptible. Score: disease severity evaluation ( 0 , resistant; 4 , susceptible). Percentage: percentage of plants with visible disease symptoms developed

PCR amplification and/or very low enzyme cleavage efficiency. On average, $4-5$ replicates per sample had to be performed to obtain single score. Therefore, these four markers were discarded from further analysis. Marker sequences were aligned to the most recent genome assembly (Zhou et al. 2018). Markers PhtjM7, InDel2, and InDel10 and are localized in the same region of the chromosome CP023117.1 (LG-05) and are separated by $108,610 \mathrm{bp}$ and $513 \mathrm{bp}$, respectively. Markers Ph258M1 and $\mathrm{Ph} 258 \mathrm{M} 2$ are flanking the sequence of $269,913 \mathrm{bp}$ in the chromosome CP023120.1 (LG-08). Alignment details are provided in Online Resource 3.

\section{At least two genetic sources of $D$. toxica resistance exist in the European L. angustifolius core collection}

The European Lupin GenBank collection of 218 L. angustifolius accessions was screened with two markers tagging the Phr1 gene (Ph258M1 and Ph258M2_dCAPS) and three markers linked to PhtjR gene (PhtjM7_dCAPS2, InDel2, and InDel10). Amplification products of expected sizes were obtained for $99.6 \%$ of samples. Additional alleles were very rare and occurred only in two lines: AN-80154a (marker Ph258M1) and W-226 (InDel2). These alleles were encoded as " $\mathrm{R}$ " homozygotes for marker validation 
procedure. Amplification consistently failed for Yorrel (PhtjM7_dCAPS2) and Badajoz-1 (InDel2). No single accession carrying R bands for all $P h r l$ and $P h t j R$ gene markers has been identified in the core collection. Therefore, it might be assumed that the analyzed germplasm array did not carry any line containing both $D$. toxica resistance genes in combination.

To enable comparison of marker genotypes with $D$. toxica resistance phenotype, a phytopathological assay in controlled environment was performed, involving 49 lines showing diverse combinations of marker scores. From 17 lines carrying both homozygous $\mathrm{R}$ alleles of Ph258M1 and Ph258M2 markers, only one (75A:258) was resistant in this experiment. From 13 lines analyzed, having at least two homozygous $\mathrm{R}$ alleles for PhtjM7, InDel2, and InDel10 markers, the resistance (or moderate resistance) was confirmed only for four accessions (Population B-551/79, Population 22695, Wonga and Tanjil). Moderate resistance was revealed also for Myallie and Boruta. These two lines carry $\mathrm{S}$ homozygous alleles for all tested markers but showed moderate resistance in one or two previous tests, respectively. On the contrary, the resistance of WTD-1406, W-226, and 83A:476, inferred from the initial controlled environment test, was not confirmed in this marker validation assay. The same phenomenon was observed for Arabella and Bojar which were revealed to be resistant in both previous tests. It should be noted that this test was highly selective, because some Australian lines reported in other studies (Shankar et al. 2002; Yang et al. 2002) as moderately resistant (Yorrel, Gunguru and Merrit) were revealed to be susceptible with an average disease scores from 3.6 to 3.8. Yet comparatively, reference lines 75A:258 and Wonga, carrying $P h r l$ and $P h t j R$ genes, were classified as resistant with scores 1.7 and 1.8 , respectively.

\section{The set of PhtjM7, InDel2, and InDel10 markers is applicable for molecular selection of PhtjR gene}

Marker genotype scores were compared with the results of this resistance survey as well as those published elsewhere. None of the markers displayed $100 \%$ consistency with $P h r 1$ and $P h t j R$ genotypes inferred from phenotypic observations or published pedigree relationships among certain narrow-leafed lupin cultivars (Cowling 1999; Shankar et al. 2002; Stefanova and Buirchell 2010; Yang et al. 2002, 2015). Markers Ph258M1 and Ph258M2 generated higher number of false-positive results than markers PhtjM7, InDel2, and InDel10, namely 21 and 30 vs 6,9 , and 8 . Low values of simple matching $(0.48$ and 0.38$)$ and Rogers-Tanimoto $(0.32$ and 0.21$)$ coefficients highlighted the negligible applicability of markers $\mathrm{Ph} 258 \mathrm{M} 1$ and Ph258M2 for molecular breeding. Markers PhtjM7, InDel2, and InDel10 revealed to have higher values of both parameters, i.e., $0.63-0.68$ for Rogers-
Tanimoto and $0.77-0.81$ for simple matching. All these three markers used together constitute relatively versatile selection tool, applicable for wide range of crosses ( $4 \%$ falsepositive and $0 \%$ false-negative scores) (Table 4 ). The correlation between marker scores and phenotype observations enabled us to conclude that resistance of Population B-551/79 and Population 22695 lines is putatively conferred by the PhtjR gene (see Online Resource 4).

\section{Discussion}

\section{$D$. toxica resistance genes in lupins}

Resistance to Phomopsis stem blight in the narrow-leafed lupin is a complex trait and at least three genes are involved, originating from different germplasm resources, namely 75A:258, Merrit, and Tanjil. The highly resistant line 75A:258 was selected from a cross between cv. Marri and a wild line collected in Morocco (P22872) (Shankar et al. 2002). Moderately resistant cultivar Merrit was derived from a cross between cv. Illyarrie and a wild line from Spain (P22750) (Gladstones 1992). Resistant cultivar Wonga was derived from a cross between Gungurru and 75A54-5-8 (Stefanova and Buirchell 2010). The studies based on $F_{1}-F_{3}$ generations of crosses Unicrop $\times 75 \mathrm{~A}: 258$ and Merrit $\times$ Unicrop revealed that both accessions carry independently segregating resistance alleles, named Phrl (75A:258) and Phr2 (Merrit) (Shankar et al. 2002). Phrl was revealed to be fully dominant, whereas $P h r 2$ appeared to be incompletely dominant. Phenotyping studies based on crosses between Tanjil and other cultivars, including the susceptible Unicrop, revealed that Tanjil and Wonga possess a single-dominant $D$. toxica resistance gene which is different from Phrl and Phr2, this gene was named PhtjR (Yang et al. 2013a). Genetic analysis of L. angustifolius material from European breeding programs (Belarus, Russia, and Poland) with reference Australian lines Merrit and Gungurru also showed that resistance to D. toxica is determined by a single dominant gene, which was named Rpll (Kuptsov et al. 2006). Several single dominant genes also control resistance against anthracnose in the narrow-leafed lupin germplasm, namely Lanrl in cv. Tanjil, AnMan in cv. Mandelup, and LanrBo in line Bo7212 (Fischer et al. 2015; Yang et al. 2004, 2008). In contrast, D. toxica resistance in another Old World lupin crop, white lupin (Lupinus albus L.), is under polygenic control as revealed by quantitative trait loci mapping in recombinant inbred line population derived from a cross between the susceptible Ukrainian cultivar Kiev Mutant and the resistant Ethiopian primitive P27174 accession (Cowley et al. 2014; Vipin et al. 2013). 
Table 4 Marker genotype scores for lines resistant to Diaporthe toxica evaluated in this study

\begin{tabular}{|c|c|c|c|c|c|c|c|c|c|}
\hline Acc. & Name & Domestication status & 2017 resistance & 2017 score & $\mathrm{Ph} 258 \mathrm{M} 1$ & $\mathrm{Ph} 258 \mathrm{M} 2$ & PhtjM7 & InDel2 & InDel10 \\
\hline 95744 & Population B-551/79 & WL & $\mathrm{R}$ & $1.4 \pm 0.7$ & S & $\mathrm{R}$ & $\mathrm{R}$ & $\mathrm{R}$ & $\mathrm{R}$ \\
\hline 26979 & $75 \mathrm{~A}: 258$ & $\mathrm{BL}$ & $\mathrm{R}$ & $1.7 \pm 1.3$ & $\mathrm{R}$ & $\mathrm{R}$ & $\mathrm{S}$ & $\mathrm{S}$ & $\mathrm{S}$ \\
\hline 96191 & Wonga & $\mathrm{CV}$ & $\mathrm{R}$ & $1.8 \pm 1.3$ & $\mathrm{~S}$ & $\mathrm{~S}$ & $\mathrm{R}$ & $\mathrm{R}$ & $\mathrm{R}$ \\
\hline 96214 & Tanjil & $\mathrm{CV}$ & $\mathrm{R}$ & $2.2 \pm 1.4$ & S & $\mathrm{S}$ & $\mathrm{R}$ & $\mathrm{R}$ & $\mathrm{R}$ \\
\hline 96231 & Myallie & $\mathrm{CV}$ & MR & $2.4 \pm 0.8$ & S & $\mathrm{S}$ & $\mathrm{S}$ & $\mathrm{S}$ & $\mathrm{S}$ \\
\hline 95944 & Population 22695 & WL & MR & $2.7 \pm 0.7$ & S & $\mathrm{R}$ & S & $\mathrm{R}$ & $\mathrm{R}$ \\
\hline 96211 & Boruta & $\mathrm{CV}$ & MR & $2.7 \pm 0.7$ & $\mathrm{~S}$ & $\mathrm{~S}$ & $\mathrm{~S}$ & $\mathrm{~S}$ & $\mathrm{~S}$ \\
\hline 95964 & Karo & $\mathrm{CV}$ & $\mathrm{S}$ & $2.8 \pm 0.8$ & $\mathrm{~S}$ & $\mathrm{R}$ & $\mathrm{S}$ & $\mathrm{S}$ & $\mathrm{S}$ \\
\hline 96219 & Kalif & $\mathrm{CV}$ & $\mathrm{S}$ & $2.8 \pm 1.6$ & $\mathrm{~S}$ & $\mathrm{~S}$ & $\mathrm{~S}$ & $\mathrm{~S}$ & $\mathrm{~S}$ \\
\hline 95737 & Population B-541/79 & WL & $\mathrm{S}$ & $2.9 \pm 0.6$ & $\mathrm{H}$ & $\mathrm{R}$ & $\mathrm{R}$ & $\mathrm{S}$ & $\mathrm{S}$ \\
\hline 96110 & Ignis & $\mathrm{CV}$ & $\mathrm{S}$ & $2.9 \pm 1.2$ & $\mathrm{~S}$ & $\mathrm{R}$ & $\mathrm{S}$ & $\mathrm{R}$ & $\mathrm{R}$ \\
\hline 96170 & $\mathrm{R} 83 \mathrm{~A}, 473$ & $\mathrm{BL}$ & $\mathrm{S}$ & $2.9 \pm 1.0$ & $\mathrm{R}$ & $\mathrm{R}$ & $\mathrm{S}$ & $\mathrm{S}$ & $\mathrm{S}$ \\
\hline 96233 & $83 \mathrm{~A}: 476$ & $\mathrm{BL}$ & $\mathrm{S}$ & $2.9 \pm 1.7$ & $\mathrm{R}$ & $\mathrm{R}$ & $\mathrm{S}$ & $\mathrm{S}$ & $\mathrm{S}$ \\
\hline 96235 & Boregine & $\mathrm{CV}$ & $\mathrm{S}$ & $2.9 \pm 1.5$ & $\mathrm{R}$ & $\mathrm{R}$ & S & $\mathrm{S}$ & $\mathrm{S}$ \\
\hline 96195 & Bolivio & $\mathrm{CV}$ & $\mathrm{S}$ & $3.0 \pm 1.4$ & $\mathrm{R}$ & $\mathrm{R}$ & S & $\mathrm{S}$ & $\mathrm{S}$ \\
\hline 96241 & Vitabor & $\mathrm{CV}$ & $\mathrm{S}$ & $3.0 \pm 1.5$ & $\mathrm{~S}$ & $\mathrm{~S}$ & S & $\mathrm{S}$ & $\mathrm{S}$ \\
\hline 96185 & Sonet & $\mathrm{CV}$ & $\mathrm{S}$ & $3.1 \pm 0.9$ & S & $\mathrm{S}$ & S & $\mathrm{S}$ & $\mathrm{S}$ \\
\hline 96212 & Zeus & $\mathrm{CV}$ & $\mathrm{S}$ & $3.1 \pm 0.9$ & S & $\mathrm{S}$ & S & $\mathrm{S}$ & $\mathrm{S}$ \\
\hline 96223 & $\mathrm{~W}-211$ & BL & $\mathrm{S}$ & $3.1 \pm 1.6$ & S & S & S & $\mathrm{S}$ & $\mathrm{S}$ \\
\hline- & Arabella & $\mathrm{CV}$ & $\mathrm{S}$ & $3.1 \pm 1.5$ & S & $\mathrm{R}$ & S & $\mathrm{S}$ & $\mathrm{S}$ \\
\hline 96230 & Mandelup & $\mathrm{CV}$ & $\mathrm{S}$ & $3.2 \pm 1.4$ & $\mathrm{R}$ & $\mathrm{R}$ & S & $\mathrm{S}$ & $\mathrm{S}$ \\
\hline 96218 & Graf & $\mathrm{CV}$ & $\mathrm{S}$ & $3.3 \pm 1.8$ & $\mathrm{~S}$ & $\mathrm{R}$ & S & $\mathrm{S}$ & $\mathrm{S}$ \\
\hline 96240 & Sonate & $\mathrm{CV}$ & $\mathrm{S}$ & $3.3 \pm 2.0$ & $\mathrm{R}$ & $\mathrm{R}$ & S & $\mathrm{S}$ & $\mathrm{S}$ \\
\hline 96102 & Unicrop & $\mathrm{CV}$ & $\mathrm{S}$ & $3.4 \pm 1.7$ & S & $\mathrm{S}$ & S & $\mathrm{S}$ & $\mathrm{S}$ \\
\hline 96113 & Frost & $\mathrm{CV}$ & $\mathrm{S}$ & $3.4 \pm 1.7$ & S & $\mathrm{R}$ & $\mathrm{R}$ & $\mathrm{S}$ & $\mathrm{S}$ \\
\hline 96224 & $\mathrm{~W}-226$ & $\mathrm{BL}$ & $\mathrm{S}$ & $3.4 \pm 1.6$ & $\mathrm{~S}$ & $\mathrm{~S}$ & $\mathrm{R}$ & $\mathrm{R}^{*}$ & $\mathrm{R}$ \\
\hline 95726 & Near Salamanca-b & WL & $\mathrm{S}$ & $3.5 \pm 0.9$ & S & $\mathrm{R}$ & $\mathrm{R}$ & $\mathrm{R}$ & $\mathrm{H}$ \\
\hline 96209 & Elf & $\mathrm{CV}$ & $\mathrm{S}$ & $3.5 \pm 2.0$ & S & $\mathrm{S}$ & $\mathrm{S}$ & $\mathrm{S}$ & $\mathrm{S}$ \\
\hline 95843 & Population 22660 & WL & $\mathrm{S}$ & $3.6 \pm 1.7$ & $\mathrm{R}$ & $\mathrm{R}$ & $\mathrm{S}$ & $\mathrm{S}$ & $\mathrm{S}$ \\
\hline 95919 & BRGC-10275 & WL & $\mathrm{S}$ & $3.6 \pm 1.9$ & $\mathrm{~S}$ & $\mathrm{R}$ & S & $\mathrm{R}$ & $\mathrm{R}$ \\
\hline 96161 & Yorrel & $\mathrm{CV}$ & $\mathrm{S}$ & $3.6 \pm 1.5$ & $\mathrm{R}$ & $\mathrm{R}$ & S & $\mathrm{S}$ & $\mathrm{S}$ \\
\hline 96225 & Bojar & $\mathrm{CV}$ & $\mathrm{S}$ & $3.6 \pm 1.2$ & $\mathrm{~S}$ & $\mathrm{~S}$ & $\mathrm{~S}$ & $\mathrm{~S}$ & $\mathrm{~S}$ \\
\hline 95711 & Badajoz 4 & WL & $\mathrm{S}$ & $3.8 \pm 1.3$ & $\mathrm{H}$ & $\mathrm{R}$ & $\mathrm{S}$ & $\mathrm{R}$ & $\mathrm{S}$ \\
\hline 96162 & Gunguru & $\mathrm{CV}$ & $\mathrm{S}$ & $3.8 \pm 2.1$ & $\mathrm{R}$ & $\mathrm{R}$ & $\mathrm{S}$ & $\mathrm{S}$ & $\mathrm{S}$ \\
\hline 96166 & Merrit & $\mathrm{CV}$ & $\mathrm{S}$ & $3.8 \pm 1.7$ & $\mathrm{R}$ & $\mathrm{R}$ & $\mathrm{S}$ & $\mathrm{S}$ & $\mathrm{S}$ \\
\hline 96371 & Population 1 & WL & $\mathrm{S}$ & $3.8 \pm 1.7$ & $\mathrm{~S}$ & $\mathrm{R}$ & $\mathrm{S}$ & $\mathrm{R}$ & $\mathrm{R}$ \\
\hline 96220 & WTD-1305 & $\mathrm{BL}$ & $\mathrm{S}$ & $3.9 \pm 1.4$ & $\mathrm{R}$ & $\mathrm{R}$ & $\mathrm{H}$ & $\mathrm{S}$ & $\mathrm{S}$ \\
\hline 95754 & Population B-575/79 & WL & $\mathrm{S}$ & $4.0 \pm 0.7$ & $\mathrm{R}$ & $\mathrm{S}$ & $\mathrm{S}$ & $\mathrm{R}$ & $\mathrm{R}$ \\
\hline 95840 & AN-80154a & WL & $\mathrm{S}$ & $4.0 \pm 1.3$ & $\mathrm{R}^{*}$ & $\mathrm{R}$ & $\mathrm{R}$ & $\mathrm{S}$ & $\mathrm{S}$ \\
\hline 96167 & $\mathrm{R} 84 \mathrm{~A}, 479$ & $\mathrm{BL}$ & $\mathrm{S}$ & $4.0 \pm 1.9$ & $\mathrm{R}$ & $\mathrm{R}$ & $\mathrm{S}$ & $\mathrm{S}$ & $\mathrm{S}$ \\
\hline 96221 & WTD-1406 & $\mathrm{BL}$ & $\mathrm{S}$ & $4.0 \pm 1.7$ & $\mathrm{R}$ & $\mathrm{R}$ & $\mathrm{S}$ & $\mathrm{S}$ & $\mathrm{S}$ \\
\hline 96183 & Wersal & $\mathrm{CV}$ & $\mathrm{S}$ & $4.2 \pm 1.6$ & S & $\mathrm{R}$ & $\mathrm{S}$ & $\mathrm{R}$ & $\mathrm{R}$ \\
\hline 95842 & Population 22661 & WL & $\mathrm{S}$ & $4.3 \pm 1.7$ & $\mathrm{R}$ & $\mathrm{R}$ & S & $\mathrm{S}$ & $\mathrm{S}$ \\
\hline 96210 & Baron & $\mathrm{CV}$ & $\mathrm{S}$ & $4.3 \pm 1.3$ & S & $\mathrm{S}$ & S & $\mathrm{S}$ & $\mathrm{S}$ \\
\hline 96222 & W-197 & $\mathrm{BL}$ & $\mathrm{S}$ & $4.3 \pm 2.0$ & $\mathrm{~S}$ & $\mathrm{~S}$ & S & $\mathrm{S}$ & $\mathrm{S}$ \\
\hline 96163 & Polonez & $\mathrm{CV}$ & $\mathrm{S}$ & $4.5 \pm 1.7$ & $\mathrm{~S}$ & $\mathrm{~S}$ & $\mathrm{~S}$ & $\mathrm{~S}$ & $\mathrm{~S}$ \\
\hline 95703 & Hinojoso de Duero 3 & WL & $\mathrm{S}$ & $4.6 \pm 1.4$ & $\mathrm{H}$ & $\mathrm{H}$ & $\mathrm{S}$ & $\mathrm{R}$ & $\mathrm{R}$ \\
\hline 95742 & Population B-549/79b & WL & $\mathrm{S}$ & $4.7 \pm 1.7$ & $\mathrm{R}$ & $\mathrm{R}$ & $\mathrm{S}$ & $\mathrm{S}$ & $\mathrm{S}$ \\
\hline 96121 & Emir & $\mathrm{CV}$ & $\mathrm{S}$ & $5.2 \pm 1.8$ & $\mathrm{~S}$ & $\mathrm{~S}$ & $\mathrm{~S}$ & $\mathrm{~S}$ & $\mathrm{~S}$ \\
\hline
\end{tabular}


Table 4 (continued)

\begin{tabular}{|c|c|c|c|c|c|c|c|c|c|}
\hline Acc. & Name & Domestication status & 2017 resistance & 2017 score & $\mathrm{Ph} 258 \mathrm{M} 1$ & $\mathrm{Ph} 258 \mathrm{M} 2$ & PhtjM7 & InDel2 & InDel10 \\
\hline 95796 & Mirela & $\mathrm{CV}$ & S & - & S & $\mathrm{R}$ & $\mathrm{S}$ & S & $\mathrm{S}$ \\
\hline 96234 & P27255 & WL & S & - & $\mathrm{R}$ & $\mathrm{R}$ & $\mathrm{S}$ & S & S \\
\hline 96196 & W-89 & BL & $\mathrm{S}$ & - & $\mathrm{S}$ & $\mathrm{S}$ & $\mathrm{S}$ & $\mathrm{S}$ & $\mathrm{S}$ \\
\hline
\end{tabular}

acc. accession, $P h$ Phomopsis stem blight resistance evaluation. Domestication status codes: $C V$ cultivar, $B L$ breeding line or cross derivative, $W L$ wild or primitive. Resistance evaluation codes: $R$ resistant, $M R$ moderately resistant, $S$ susceptible. Marker genotype scores: $R$ resistant allele, $H$ heterozygote, $S$ susceptible allele

*Additional allele present besides $\mathrm{R}$ allele

\section{Tools for marker-assisted selection}

At the time of their development, markers Ph258M1 and $\mathrm{Ph} 258 \mathrm{M} 2$ were considered as useful for marker-assisted selection, with, however, a limited range of target crosses due to presence of false-positive scores in domesticated Australian germplasm, including cv. Merrit. This phenomenon resulted from the large distance between these markers and the Phrl gene, estimated to be 7.8 and $5.7 \mathrm{cM}$, respectively (Yang et al. 2002). Our study supported this observation providing evidence for both the occurrence of false-positive scores (accounting for $40-58 \%$ of analyzed lines) and the high rate of recombination between the markers (30\% analyzed of lines, of which $63 \%$ were wild and $37 \%$ domesticated), see Online Resource 4. Better markers have not yet been developed because both existing $L$. angustifolius mapping populations are monomorphic for Phrl gene and could not be exploited to solve this issue (Boersma et al. 2005; Yang et al. 2013b). Harnessing of next-generation sequencing techniques based on whole-genome resequencing of reference resistant and susceptible lines may help to overcome this barrier in the near future and facilitate generation of high-quality, cost-effective markers, as it was the case for L. angustifolius anthracnose resistance (Yang et al. 2015).

Markers InDel2 and InDel10 originated from scaffold 84773 carrying the putative $P h t j R$ resistance gene and were considered to be truly diagnostic since the marker genotypes were consistent with Phomopsis stem blight resistance phenotypes on all Australian cultivars analyzed (Yang et al. 2015). Our study showed that they are also diagnostic on a wide range of accessions from the European germplasm collection, including cultivars and breeding lines. We identified only three incidences of recombination events between InDel2 and InDel10 markers, which all occurred only in wild populations (Online Resource 4). Additionally, three heterozygote scores were found for InDel10, also only in wild populations. Marker PhtjM7, located roughly $1 \mathrm{cM}$ from the target $P h t j R$ gene, was originally recommended as applicable for markerassisted selection in narrow-leafed lupin breeding due to the lack of recombination between the marker and the gene in the set of 26 Australian cultivars; expected genotyping accuracy was estimated to be approximately $99 \%$ (Yang et al. 2013a). However, we identified the presence of recombination between PhtjM7 and InDel2 or InDel10 markers in as many as 30 lines, including 22 wild and 8 domesticated lines. Nevertheless, this marker had slightly higher genotype to phenotype similarity coefficients than InDel2 or InDel10 in the validation assay. All three markers used together provided 95\% confidence on selection of the desirable PhtjR allele.

The most reliable markers for genotype selection are those anchored in functional mutations of genes conferring particular traits, as was established for $L$. angustifolius vernalization responsiveness locus $K u$ and corresponding large deletion in the promoter region of Flowering locus Thomolog, LanFTcl gene (Nelson et al. 2017). Nevertheless, deciphering the molecular background underlying the $K u$ locus took more than decade of extensive research involving various techniques, from BAC library screening via DNA hybridization, restriction siteassociated physical and linkage mapping, fluorescent in situ hybridization of DNA probes in metaphase chromosomes, Sanger, 454 and Hi-seq sequencing to gene expression profiling (Książkiewicz et al. 2016; Nelson et al. 2017, 2006). Although a similar BAC library approach was applied to L. angustifolius Phomopsis stem blight resistance markers PhtjM2 (linked with PhtjR) and Ph258M2 (Phr1), it did not yield resistance gene identification or the development of tightly linked diagnostic markers (Książkiewicz et al. 2013, 2015). Those studies showed convincingly that MFLP-derived probes are not suitable for positional cloning of particular genes because they hybridize to numerous loci dispersed in the genome, localized both in repetitive and gene-rich regions.

The falling price of sequencing and the increase in the size of sequence databases has reduced the cost of obtaining useful sequence information for analysis (Muir et al. 2016). Accelerating progress in next-generation sequencing technology and annotation has considerably shortened the time and money required for identifying genes controlling agronomic traits, as was demonstrated for $L p P g 1$ stem rust resistance locus in perennial ryegrass (Lolium perenne) where the NBS-LRR gene was revealed through massive analysis of cDNA ends (MACE) (Bojahr et al. 2016). The MACE approach has also been implemented in L. angustifolius applied 
research, aimed at providing ready-to-use technology for gene-based monitoring of key agronomic traits including, among others, resistance to pathogenic fungi (Książkiewicz et al. unpublished).

Both identified resistant wild lines (Population B-551/79 and Population 22695) originate from Spain. The geographical localization of these putative resistance donors in warm Mediterranean climates coincides with the ecological niche of the pathogen. Thus, in controlled conditions, the maximum infection efficiency was observed after a dew period of 48-72 h with temperatures within a range of $15-25^{\circ} \mathrm{C}$ with $20^{\circ} \mathrm{C}$ being the optimum (Williamson and Sivasithamparam 1994). In Australian field conditions, infections and subsequent lupinosis appearance were determined to be correlated with rainfall patterns (Cowling and Wood 1989; Petterson and Wood 1986). Phomopsis stem blight has been considered by European lupin breeders as an unimportant disease, constituting a threat to white lupin only in wet years (Święcicki and Święcicki 1995). However, the advance of global warming may expand the D. toxica climatic optimum in to the north, reaching major European areas of lupin cultivation and forcing adaptation of breeding strategies to develop crop cultivars adapted to new threats. Unfortunately, much of the natural genetic diversity in narrow-leafed lupin has been lost during the domestication process (Berger et al. 2012). Incorporation of alleles from wild germplasm to widen the genetic diversity of the domesticated pool is currently emerging as an important need of the narrowleafed lupin breeding community (Berger et al. 2013). This process may be facilitated by using PhtjR molecular markers validated in this study for European lupin germplasm.

\section{Conclusions}

1. The European lupin germplasm collection preserves wild and domesticated donors of at least two Phomopsis stem blight resistance genes, $P h r l$ and $P h t j R$.

2. The set of molecular markers PhtjM7, InDel2, and InDel10, tagging the PhtjR gene, can be used in markerassisted selection targeting the European gene pool with an expected confidence about $95 \%$.

3. By now, no reliable diagnostic marker for the Phrl applicable for European breeding programs has been found; the two existing markers showed high percentage of false-positive results and high recombination rates between markers.

Acknowledgments The authors are thankful to Dr. William Truman from IPG PAS for thorough revision of the manuscript.

Authors' contributions MK planned and coordinated the whole study. MJ designed the phytopathological experiments. MK analyzed the results and drafted the manuscript. PP, ER, WB, and SR performed marker optimization and the genotyping of $L$. angustifolius. WI performed molecular analysis of $D$. toxica isolates to facilitate selection of strains for disease resistance experiments. KW, JK, and MJ evaluated Phomopsis stem blight resistance in field and controlled environment conditions. MJ wrote parts of the manuscript concerning the phytopathological studies. MJ corrected the whole manuscript. All authors contributed to the final version of the manuscript.

Funding information Research was funded by Polish National Science Centre (grant no. 2015/17/D/NZ9/02112). The isolates of D. toxica from Australia were kindly donated by Dr. Manisha Shankar, senior plant pathologist from the Department of Agriculture and Food, Western Australia (DAFWA, Perth, AU). The isolates of D. toxica from Poland are a part of the collection of phytopathogenic fungi gathered by the Department of Pathogen Genetics and Plant Resistance of the Institute of Plant Genetics, Polish Academy of Sciences (Poznań, PL).

\section{Compliance with ethical standards}

Conflict of interest The authors declare that they have no conflict of interests.

Human and animal rights This article does not contain any studies with human participants or animals, performed by any of the authors.

Open Access This article is distributed under the terms of the Creative Commons Attribution 4.0 International License (http:// creativecommons.org/licenses/by/4.0/), which permits unrestricted use, distribution, and reproduction in any medium, provided you give appropriate credit to the original author(s) and the source, provide a link to the Creative Commons license, and indicate if changes were made.

\section{References}

Berger JD, Buirchell BJ, Luckett DJ, Nelson MN (2012) Domestication bottlenecks limit genetic diversity and constrain adaptation in narrow-leafed lupin (Lupinus angustifolius L). Theor Appl Genet 124:637-652. https://doi.org/10.1007/s00122-011-1736-z

Berger JD, Clements JC, Nelson MN, Kamphuis LG, Singh KB, Buirchell B (2013) The essential role of genetic resources in narrow-leafed lupin improvement. Crop Pasture Sci 64:361-373. https://doi.org/10.1071/CP13092

Boersma JG, Pallotta M, Li C, Buirchell BJ, Sivasithamparam K, Yang H (2005) Construction of a genetic linkage map using MFLP and identification of molecular markers linked to domestication genes in narrow-leafed lupin (Lupinus angustifolius L). Cell Mol Biol Lett 10:331-344

Bojahr J, Nhengiwa O, Krezdorn N, Rotter B, Saal B, Ruge-Wehling B, Struck C, Winter P (2016) Massive analysis of cDNA ends (MACE) reveals a co-segregating candidate gene for $\mathrm{LpPg} 1$ stem rust resistance in perennial ryegrass (Lolium perenne). Theor Appl Genet 129:1915-1932. https://doi.org/10.1007/s00122-016-2749-4

Cernay C, Ben-Ari T, Pelzer E, Meynard J-M, Makowski D (2015) Estimating variability in grain legume yields across Europe and the Americas. Sci Rep 5:11171. https://doi.org/10.1038/srep11171

Cowley R, Luckett DJ, Ash GJ, Harper JDI, Vipin CA, Raman H, Ellwood S (2014) Identification of QTLs associated with resistance to Phomopsis pod blight (Diaporthe toxica) in Lupinus albus. Breed Sci 64:83-89. https://doi.org/10.1270/jsbbs.64.83

Cowling WA (1999) Pedigrees and characteristics of narrow-leafed lupin cultivars released in Australia from 1967 to 1998. Bull Agric West Aust 4365:4-11. https://doi.org/10.13140/RG.2.1.1441.1600 
Cowling W, Wood P (1989) Resistance to Phomopsis stem and pod blight of narrow-leafed lupin in a range of environments and its association with reduced Phomopsis seed infection. Aust J Exp Agric 29:43-50. https://doi.org/10.1071/EA9890043

Cowling WA, Hamblin J, Wood PM, Gladstones JS (1987) Resistance to Phomopsis stem blight in Lupinus angustifolius L. Crop Sci 27:648652 . https://doi.org/10.2135/cropsci 1987 . 0011183X002700040007x

Fischer M (1893) Zur Entwiklungsgeschichte des Cryptosporium leptostromiforme J. Kuhn. Botanisches Zentralblatt

Fischer K, Dieterich R, Nelson MN, Kamphuis LG, Singh KB, Rotter B, Krezdorn N, Winter P, Wehling P, Ruge-Wehling B (2015) Characterization and mapping of LanrBo: a locus conferring anthracnose resistance in narrow-leafed lupin (Lupinus angustifolius L.). Theor Appl Genet 128:2121-2130. https://doi.org/10.1007/ s00122-015-2572-3

Gao L-L, Hane JK, Kamphuis LG, Foley R, Shi B-J, Atkins CA, Singh KB (2011) Development of genomic resources for the narrow-leafed lupin (Lupinus angustifolius): construction of a bacterial artificial chromosome (BAC) library and BAC-end sequencing. BMC Genomics 12:521. https://doi.org/10.1186/1471-2164-12-521

Gladstones J (1992) Lupinus angustifolius L. (narrow-leafed lupin) cv. Merrit. Aust J Exp Agric 32:265-265. https://doi.org/10.1071/ EA9920265

Hackbarth J, Troll HJ (1956) Die Lupinen als Körnerleguminosen und Futterpflanzen. In: Handbuch der Pflanzenzüchtung. Verlag Paul Parey, Berlin, pp 1-51

Hane JK, Ming Y, Kamphuis LG, Nelson MN, Garg G, Atkins CA, Bayer PE, Bravo A, Bringans S, Cannon S, Edwards D, Foley R, Gao LL, Harrison MJ, Huang W, Hurgobin B, Li S, Liu CW, McGrath A, Morahan G, Murray J, Weller J, Jian J, Singh KB (2017) A comprehensive draft genome sequence for lupin (Lupinus angustifolius), an emerging health food: insights into plant-microbe interactions and legume evolution. Plant Biotechnol J 15:318-330. https://doi.org/ 10.1111/pbi.12615

Jago MV, Peterson JE, Payne AL, Campbell DG (1982) Lupinosis: response of sheep to different doses of phomopsin. Aust J Exp Biol Med Sci 60:239-251. https://doi.org/10.1038/icb.1982.29

Kamel KA, Święcicki W, Kaczmarek Z, Barzyk P (2016) Quantitative and qualitative content of alkaloids in seeds of a narrow-leafed lupin (Lupinus angustifolius L.) collection. Genet Resour Crop Evol 63: 711-719. https://doi.org/10.1007/s10722-015-0278-7

Kamphuis LG, Hane JK, Nelson MN, Gao L, Atkins CA, Singh KB (2015) Transcriptome sequencing of different narrow-leafed lupin tissue types provides a comprehensive uni-gene assembly and extensive gene-based molecular markers. Plant Biotechnol J 13:14-25. https://doi.org/10.1111/pbi.12229

Kasprzak A, Safár J, Janda J, Dolezel J, Wolko B, Naganowska B (2006) The bacterial artificial chromosome (BAC) library of the narrowleafed lupin (Lupinus angustifolius L). Cell Mol Biol Lett 11:396407. https://doi.org/10.2478/s11658-006-0033-3

Konieczny A, Ausubel FM (1993) A procedure for mapping Arabidopsis mutations using co-dominant ecotype-specific PCR-based markers. Plant J 4:403-410. https://doi.org/10.1046/j.1365-313X.1993. 04020403.x

Książkiewicz M, Wyrwa K, Szczepaniak A, Rychel S, Majcherkiewicz K, Przysiecka Ł, Karlowski W, Wolko B, Naganowska B (2013) Comparative genomics of Lupinus angustifolius gene-rich regions: BAC library exploration, genetic mapping and cytogenetics. BMC Genomics 14:79. https://doi.org/10.1186/1471-2164-14-79

Książkiewicz M, Zielezinski A, Wyrwa K, Szczepaniak A, Rychel S, Karlowski W, Wolko B, Naganowska B (2015) Remnants of the legume ancestral genome preserved in gene-rich regions: insights from Lupinus angustifolius physical, genetic, and comparative mapping. Plant Mol Biol Rep 33:84-101. https://doi.org/10.1007/ s11105-014-0730-4
Książkiewicz M, Rychel S, Nelson MN, Wyrwa K, Naganowska B, Wolko B (2016) Expansion of the phosphatidylethanolamine binding protein family in legumes: a case study of Lupinus angustifolius L. FLOWERING LOCUS T homologs, LanFTc1 and LanFTc2. BMC Genomics 17:820. https://doi.org/10.1186/s12864-016-3150Z

Kuptsov V, Kolomiets EM, Kuptsov N, Joernsgaard B (2006) Environmentally friendly methods to combat fungal diseases of lupin. In: México, where old and new world lupins meet. Proceedings of the 11th International Lupin Conference, 4-9 May, Guadalajara, Jalisco, Mexico, 2005. International Lupin Association, Canterbury, pp 135-138

Leśniewska K, Książkiewicz M, Nelson MN, Mahé F, Aïnouche A, Wolko B, Naganowska B (2011) Assignment of 3 genetic linkage groups to 3 chromosomes of narrow-leafed lupin. J Hered 102:228 236. https://doi.org/10.1093/jhered/esq107

Lewartowska E, Jędryczka M, Frencel I, Pieczyrak J (1994) Seed-borne fungi of Lupinus angustifolius L. cultivars Phytopathologia. Polonica 7:123-130

Lind JVA (1913) Danish fungi as represented in the herbarium of E. Rostrup. Gyldendalske Boghandel - Nordisk Forlag, Copenhagen

Lucas MM, Stoddard FL, Annicchiarico P, Frías J, Martínez-Villaluenga C, Sussmann D, Duranti M, Seger A, Zander PM, Pueyo JJ (2015) The future of lupin as a protein crop in Europe. Front Plant Sci 6: 705. https://doi.org/10.3389/fpls.2015.00705

Marcinkowska J (2007) Reappearance of Phomopsis leptostromiformis on yellow lupine in Poland Phytopathol Pol:67-69

Muir P, Li S, Lou S, Wang D, Spakowicz DJ, Salichos L, Zhang J, Weinstock GM, Isaacs F, Rozowsky J, Gerstein M (2016) The real cost of sequencing: scaling computation to keep pace with data generation. Genome Biol 17:53. https://doi.org/10.1186/s13059016-0917-0

Naganowska B, Wolko B, Sliwińska E, Kaczmarek Z (2003) Nuclear DNA content variation and species relationships in the genus Lupinus (Fabaceae). Ann Bot 92:349-355. https://doi.org/10.1093/ aob/mcg145

Neff MM, Neff JD, Chory J, Pepper AE (1998) dCAPS, a simple technique for the genetic analysis of single nucleotide polymorphisms: experimental applications in Arabidopsis thaliana genetics. Plant $\mathbf{J}$ 14:387-392. https://doi.org/10.1046/j.1365-313X.1998.00124.x

Neff MM, Turk E, Kalishman M (2002) Web-based primer design for single nucleotide polymorphism analysis. Trends Genet 18:613615. https://doi.org/10.1016/S0168-9525(02)02820-2

Nelson MN, Phan HTT, Ellwood SR, Moolhuijzen PM, Hane J, Williams A, O'Lone CE, Fosu-Nyarko J, Scobie M, Cakir M, Jones MGK, Bellgard M, Ksiazkiewicz M, Wolko B, Barker SJ, Oliver RP, Cowling WA (2006) The first gene-based map of Lupinus angustifolius L.-location of domestication genes and conserved synteny with Medicago truncatula. Theor Appl Genet 113:225238. https://doi.org/10.1007/s00122-006-0288-0

Nelson MN, Książkiewicz M, Rychel S, Besharat N, Taylor CM, Wyrwa K, Jost R, Erskine W, Cowling WA, Berger JD, Batley J, Weller JL, Naganowska B, Wolko B (2017) The loss of vernalization requirement in narrow-leafed lupin is associated with a deletion in the promoter and de-repressed expression of a Flowering Locus $T$ (FT) homologue. New Phytol 213:220-232. https://doi.org/10. 1111/nph.14094

Peoples MB, Brockwell J, Herridge DF, Rochester IJ, Alves BJR, Urquiaga S, Boddey RM, Dakora FD, Bhattarai S, Maskey SL, Sampet C, Rerkasem B, Khan DF, Hauggaard-Nielsen H, Jensen ES (2009) The contributions of nitrogen-fixing crop legumes to the productivity of agricultural systems. Symbiosis 48:1-17. https://doi.org/10.1007/bf03179980

Petterson DS, Wood PMR (1986) Phomopsis infection of lupin seed. J Agric West Aust 27:53-54 
Przysiecka Ł, Książkiewicz M, Wolko B, Naganowska B (2015) Structure, expression profile and phylogenetic inference of chalcone isomerase-like genes from the narrow-leafed lupin (Lupinus angustifolius L.) genome. Front Plant Sci 6:268. https://doi.org/10. 3389/fpls.2015.00268

Rogers DJ, Tanimoto TT (1960) A Computer program for classifying plants. Science 132:1115-1118. https://doi.org/10.1126/science. 132.3434.1115

Shankar M, Cowling WA, Sweetingham MW (1996) The expression of resistance to latent stem infection by Diaporthe toxica in narrowleafed lupins. Phytopathology:692-697. https://doi.org/10.1094/ Phyto-86-692

Shankar M, Sweetingham MW, Cowling WA (2002) Identification of alleles at two loci controlling resistance to Phomopsis stem blight in narrow-leafed lupin (Lupinus angustifolius L). Euphytica 125:3544. https://doi.org/10.1023/A:1015704728492

Sokal RR, Michener CD (1958) A statistical method for evaluating systematic relationships. Univ Kans Sci Bull 28:1409-1438

Stefanova KT, Buirchell B (2010) Multiplicative mixed models for genetic gain assessment in lupin breeding. Crop Sci 50:880-891. https://doi.org/10.2135/cropsci2009.07.0402

Święcicki W, Święcicki WK (1995) Domestication and breeding improvement of narrow-leafed lupin (L. angustifolius L.), J Appl Genet. 36:155-167

Untergasser A, Nijveen H, Rao X, Bisseling T, Geurts R, Leunissen JAM (2007) Primer3Plus, an enhanced web interface to Primer3. Nucleic Acids Res 35:W71-W74. https://doi.org/10.1093/nar/gkm306

Vipin CA, Luckett DJ, Harper JDI, Ash GJ, Kilian A, Ellwood SR, Phan HTT, Raman H (2013) Construction of integrated linkage map of a recombinant inbred line population of white lupin (Lupinus albus L.). Breed Sci 63:292-300. https://doi.org/10.1270/jsbbs.63.292

Williamson P, Sivasithamparam K (1994) Factors influencing the establishment of latent infection of narrow-leafed lupins by Diaporthe toxica. Aust J Agric Res 45:1387-1394. https://doi.org/10.1071/ AR9941387

Williamson PM, Sivasithamparam K, Cowling WA (1991) Formation of subcuticular coralloid hyphae by Phomopsis leptostromiformis upon latent infection of narrow-leafed lupins. Plant Dis 75:1023-1026. https://doi.org/10.1094/PD-75-1023

Williamson PM, Highet AS, Gams W, Sivasithamparam K, Cowling WA (1994) Diaporthe toxica sp. nov., the cause of lupinosis in sheep. Mycol Res 98:1364-1368. https://doi.org/10.1016/S0953-7562(09) 81064-2

Wyrwa K, Książkiewicz M, Szczepaniak A, Susek K, Podkowiński J, Naganowska B (2016) Integration of Lupinus angustifolius L. (narrow-leafed lupin) genome maps and comparative mapping within legumes. Chromosome Res 24:355-378. https://doi.org/10.1007/ s10577-016-9526-8

Yang H, Tao Y, Zheng Z, Shao D, Li Z, Sweetingham MW, Buirchell BJ, Li C (2013a) Rapid development of molecular markers by nextgeneration sequencing linked to a gene conferring phomopsis stem blight disease resistance for marker-assisted selection in lupin (Lupinus angustifolius L.) breeding. Theor Appl Genet 126:511522. https://doi.org/10.1007/s00122-012-1997-1

Yang H, Tao Y, Zheng Z, Zhang Q, Zhou G, Sweetingham MW, Howieson JG, Li C (2013b) Draft genome sequence, and a sequence-defined genetic linkage map of the legume crop species Lupinus angustifolius L. PloS One 8:e64799. https://doi.org/10. 1371/journal.pone.0064799

Yang H, Jian J, Li X, Renshaw D, Clements J, Sweetingham MW, Tan C, Li C (2015) Application of whole genome re-sequencing data in the development of diagnostic DNA markers tightly linked to a diseaseresistance locus for marker-assisted selection in lupin (Lupinus angustifolius). BMC Genomics 16:660. https://doi.org/10.1186/ s12864-015-1878-5

Yang H, Shankar M, Buirchell J, Sweetingham W, Caminero C, Smith C (2002) Development of molecular markers using MFLP linked to a gene conferring resistance to Diaporthe toxica in narrow-leafed lupin (Lupinus angustifolius L). Theor Appl Genet 105:265-270. https://doi.org/10.1007/s00122-002-0925-1

Yang H, Boersma JG, You M, Buirchell BJ, Sweetingham MW (2004) Development and implementation of a sequence-specific PCR marker linked to a gene conferring resistance to anthracnose disease in narrow-leafed lupin (Lupinus angustifolius L). Mol Breed 14: 145-151. https://doi.org/10.1023/B:MOLB.0000038003.49638.97

Yang H, Renshaw D, Thomas G, Buirchell B, Sweetingham M (2008) A strategy to develop molecular markers applicable to a wide range of crosses for marker assisted selection in plant breeding: a case study on anthracnose disease resistance in lupin (Lupinus angustifolius L). Mol Breed 21:473-483. https://doi.org/10.1007/s11032-007-9146-2

Zhou G, Jian J, Wang P, Li C, Tao Y, Li X, Renshaw D, Clements J, Sweetingham M, Yang H (2018) Construction of an ultra-high density consensus genetic map, and enhancement of the physical map from genome sequencing in Lupinus angustifolius. Theor Appl Genet 131:209-223. https://doi.org/10.1007/s00122-017-2997-y

Publisher's note Springer Nature remains neutral with regard to jurisdictional claims in published maps and institutional affiliations. 